\title{
Study on the Effect Analysis of the Intensive Reading and Writing Task in English Major Teaching on the Critical Thinking Ability
}

\author{
Xiong Shengqi, Lv Hongmei \\ Nanchang Institute of Science \&Technology,Nanchang 330108,China
}

Keywords: Speculative ability, Intensive reading and writing, English teaching.

\begin{abstract}
In recent years, there has been a common understanding in the aspects of strengthening the cultivation of students' thinking ability, but these have promoted the study of how to cultivate the students' thinking ability in English skill teaching. In the teaching of English majors, the research on the cultivation of students' critical thinking ability is relatively small. This paper develops the intensive reading and writing task to study the cultivation of students' critical thinking ability in a college English major's English and American literature course, it is proved that the intensive reading and writing task is significant to improve students' reasoning ability, but also can promote students' professional knowledge and improve their writing ability. This research has certain reference significance for the teachers engaged in the teaching of English majors.
\end{abstract}

\section{Introduction}

In recent years, with the reform of our country English major, the development of students' thinking ability is more and more recognized,and the development of thinking ability has become one of the core objectives of higher education in China [1-3]. In our country, the national long-term education reform and development plan in 2010-2020 pointed out the training of strengthening the students innovation ability and thinking ability. In the course of professional course teaching, we should strengthen the innovation ability and the creative ability of finding problems, solving problems, and so on, and have conscious training students' abstract and summary, analysis and comprehensive, multi-angle analysis of the problem and thinking ability. It can be seen that the strengthening students' thinking ability not only should be the responsibility in the teaching of workers, but also China's major strategic plan [4-6]. However, the study of strengthening students' thinking ability is mainly concentrated in the course of English reading, speaking and writing and so other skill, and the report of professional knowledge teaching courses is less such as literature. At present, the professional English learning of the university undergraduate course not only includes the English skills course learning, but also includes a lot of English professional knowledge learning, which makes us also raised a requirement on the students thinking ability training, we should not only pay attention to the cultivation of students' critical thinking in skill class, we should push into a new class, and should also develop students' critical thinking skills training related research in English professional knowledge course, which are crucial for the whole of English majors teaching, but also can promote the teaching quality $[7,8]$. This paper briefly introduces the research on the cultivation of students' critical thinking ability in the course of English and American literature teaching,it is hoped that the results of the action can provide some reference for the people who are engaged in the English majors knowledge teaching.

\section{Discussion on the Thinking Ability}

The concept of thinking ability. Speculative ability comes from the English critical thinking skills, some scholars in our country also translate it into critical thinking, thinking ability and so on [9]. Sometimes, the speculative ability has also been described as a purpose, it can produce the judgment of self-regulatory role, its existence will produce the analysis and evaluation on the evidence category, concept category, method and a series of factors, and the judgment is derived from the premise of the analysis and evaluation [10]. Speculative ability not only includes people's cognitive ability, but also includes the emotional characteristics, cognitive ability includes analysis, 
reasoning, evaluation and other 3 skills, and emotional traits includes curiosity, openness, confidence, integrity and perseverance and other 5 kinds of personality. The thinking ability is the embodiment of innovation and diversity, it provides students with a more diverse perspective to describe the phenomenon, it can also put forward a variety of analysis and judgment, and then can put forward a variety of means to solve the problem.

Research on the thinking ability. For the study of the thinking ability, foreign countries have carried out the relevant research, and the results are endless. Their research contents can be divided into 3 categories, in which one is the distinction between the sub capacity of speculative ability; two is to build the measuring of speculative ability; three is the study of thinking ability training way in college teaching [11]. On the composition of the critical thinking skills, both at home and abroad are discussed related, such as Delphi project group's two dimensional structure critical thinking ability model, Paul and elder's ternary structure critical thinking ability model, Lin Chongde's triangular structure thinking ability model and Wen Qiufang's thinking ability level theoretical model. In above multiple models mentioned, the level of reasoning ability hierarchy model has a great impact on the characteristics of simplicity, clarity, practicality and so on.

Wen Qiufang's speculative ability level theory model is divided into two levels, the first level is the meta speculative ability, which is a kind of speculative planning, view, integration and evaluation skills; the second level is the thinking ability, it includes two aspects, one is the cognitive skills, and another is the emotional characteristics [12]. In the process of constructing the thinking ability theory model, Wen Qiufang has carried out relevant experiments in the process of reading her students' literature reading, the results have proved that the model is effective, and the students can improve the thinking ability based on the cognitive skills and emotional characteristics. Thus, the thinking ability level theory has the remarkable training effect for English major students, and are also same practical for non English major students.

Research on the current situation of higher education thinking ability teaching. In the 1950s, educational psychologists Bloom Benjamin in United States put forward that educational objectives were divided into three major areas, including emotional goal, action skill goal and cognitive goal, and we should pay attention to the cultivation of cognitive ability. Through the research and development of the former third level cognitive ability, Blum Anderson put forward a 6 level model. The Blum Anderson model is shown in Figure 1.

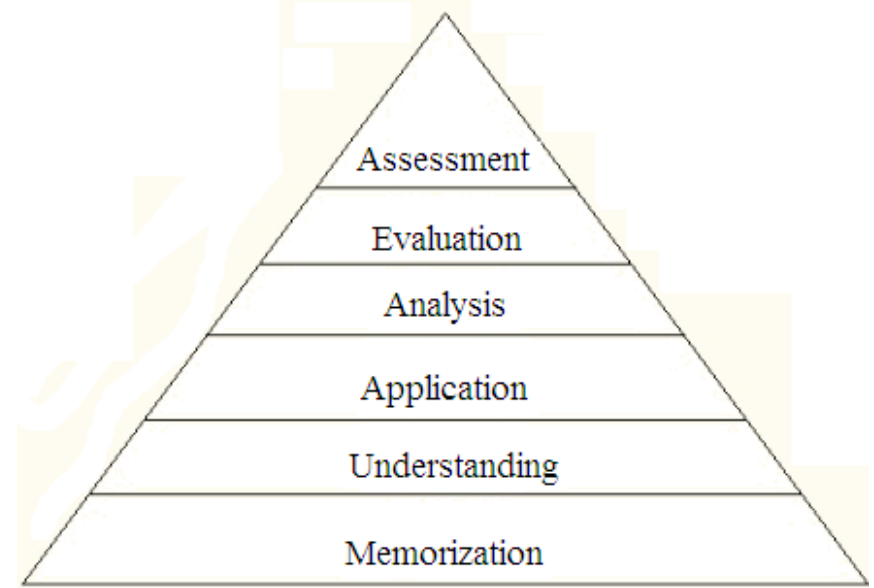

Fig. Blum Anderson cognitive model classification

In the 1980's, the thinking ability has already become one of the main targets of American higher education, and the educational circles of the United States have begun to research on the cultivation of the ability of thinking. Of course, the development of interdisciplinary research is mainly concentrated in psychology, education, sociology, information science and business, the research report of the critical ability is relatively scarce in the process of language knowledge teaching.

In recent years, the domestic English scholars have realized the urgency and necessity of strengthening the cultivation of students' thinking ability. Now, the research of the thinking ability of English education circle is mainly focused on the study in English skills, and there is relatively few reports for the English professional knowledge class. 
In colleges, the teaching of English professional knowledge mainly through the teacher class way, the teacher questions have become the main means of communication between teachers and students for this traditional way, and occasional classroom discussion is also possible. However, this traditional teaching mode is influenced by the students' course knowledge mastery, the preview before class and the class enthusiasm, the discussion of the income is less, which leads to the low efficiency of the traditional teaching mode. In view of this, school teachers in the British and American literature courses carry out the teaching of English professional knowledge to improve the action of students' think ability, but also make corresponding adjustments for the British and American literature curriculum teaching plan, to explore innovation for the new teaching methods.

Improving the thinking ability for intensive reading and writing tasks. As is known to all, writing is a special learning method, which can make us learn more quickly and better. The process of writing allows us to express what we know, and it also allows us to have a better understanding of our own knowledge level. For our own understanding, we can formulate the corresponding plan, to improve the learning enthusiasm and learning efficiency [13]. At the same time, writing is to learn, writing can help us to straighten out ideas, let us clear headed to promote thinking, and making our language can be a good expression of our thoughts. Therefore, writing makes our thinking more specific, a lot of students can not write clearly in the writing process, and it is precisely because of the unclear. It is precisely because of the unique nature of writing, the students' thinking ability can be improved from the writing, but also there are also relevant studies confirmed this view.

The purpose of our professional knowledge courses is to promote students understanding relevant knowledge, so that students have the ability to use professional knowledge to practice. Therefore, students must first through a large number of reading to obtain the necessary knowledge, so as to the need for writing.

\section{Research Project Design and Results}

This study intends to solve the problem that is how to improve the students' thinking ability in English and American literature course, and we want to achieve this goal that is the student's intensive reading and writing tasks. Through the development of students' intensive reading and writing tasks, we can improve students' thinking ability.

Scheme design. The teacher makes a corresponding adjustment for the curriculum of English and American Literature:

(1) The first week is to do a brief introduction for the course, and the next three weeks introduces the main theories and concepts of British and American literature, the rest of the week analyzes the corresponding period of the relationship between the British and American literature and development by the use of British and American literature related knowledge.

(2) the students who take part in the study action have to read the article on average 5-7 pages per week, and they write a reading report according to the reading of these the articles. The teacher should do a good job in the report collection, so that the classification is easy for the future. Teachers make the corresponding requirements for the reading report. According to the content of the article, this paper divides genre, and we try to describe the ideas of the genre in a short word; we describe about the view of different schools, and tell the similarities and differences between them; we try to comment on the list of schools.

(3) The classroom changes the past teaching style, the teachers as the supporting role play a leading role, and the students as the leading role discuss the reading article and writing.

Program results. The students who participate in this study have 22 students, we collect the syllabus of their course, writing templates and their reading reports, and finally talk with the students. Through the analysis of the students' reading report scoring, the final reading report scores as well as conversations situation analysis with students, the action plan can improve the effect of students' thinking ability.

According to the theoretical model of critical thinking ability, students need to write the corresponding reading report, they must use the speculative ability theory model, that is the part of cognitive skills, including analysis and evaluation. The teacher's request for reading report is the test 
and improvement of students' analytical skills and evaluation skills. We compare the evaluation standard of speculative theoretical model, that is clearly, relevance, logic, profundity and flexibility. Reading the report make by students is scored, in which "1-20" represents very poor, "21-40" represents fair, “41-60” represents good, and "81-100" represents excellent.

In the first 4 weeks, the performance of the students are relatively good. From the beginning of the fifth week, the students must write a reading report in accordance with the given requirements of the teacher, which requires students to use thinking skills to complete the corresponding reading report. Through the student's reading report, we can understand the change of students' thinking ability. The 5-14 weeks reading report's scores are shown in Table 1.

Table 1 . The reading report scores

\begin{tabular}{|l|c|c|c|}
\hline \multicolumn{1}{|c|}{ Week number } & The number of people & Average score & Rank \\
\hline Fifth weeks & 22 & 37.3 & Fair \\
\hline Sixth weeks & 22 & 49.2 & Better \\
\hline Seventh weeks & 22 & 54.5 & Better \\
\hline Eighth weeks & 22 & 63.2 & Good \\
\hline Ninth weeks & 22 & 72.5 & Good \\
\hline Tenth weeks & 22 & 83.2 & Excellent \\
\hline Eleventh weeks & 22 & 85.9 & Excellent \\
\hline Twelfth weeks & 22 & 90.3 & Excellent \\
\hline Thirteenth weeks & 22 & 95.6 & Excellent \\
\hline Fourteenth weeks & 22 & 97.6 & \\
\hline
\end{tabular}

As shown in Table 1, it can be seen that, the average score of reading report is increasing with the increase of time, while reading report score is a reflection of the thinking ability. With the increase of the score, students' thinking ability is increasing, which shows that this scheme has a great effect on the cultivation of students' thinking ability.

After the entire study is done, the students are talking to the students who participated in the action, and the conversation is carried on one to one. The main contents of the conversation includes the views of this course, the harvest through reading report writing and the receiving of the entire course. The results of the conversation are consistent with the results of the above analysis, and the students' thinking ability has been greatly improved.

\section{Summary}

This study use professional knowledge in English teaching process to cultivate students' thinking ability, and we achieve great success, so the professional courses can also play a big role in cultivating students' thinking ability. In the future research, we should give some attention to professional courses, students can enhance the ability of critical thinking through a large number of training, and the training is a combination of reading and writing, the professional courses for students is a kind of very good for learning knowledge. The results of this study are successful, and also to achieve the desired results. However, the teaching method occupies a large amount of time, the students can not be too many, but this teaching mode has a certain reference value for the professional knowledge of English teaching teachers.

\section{References}

[1] X.R. Zhao. Research on the cultivation of students' critical thinking ability in the teaching of ideological and political education. Hebei Normal University, 2014: 1-12.

[2] R. Zhang. The cultivation of critical thinking ability in the grammar teaching. China Western technology, 2013(8): 118-119. 
[3] Y.X. Zhang, C.P. Zhang, Y. Wang. The ignored soft power in English learning- thinking ability absent reason analysis. Science Herald, 2015(3): 28-29.

[4] J.J. Hao. Inquiry study of the college foreign language teachers in the teaching practice. Journal of Qilu Normal University, 2015(4): 25-30.

[5] Z.J. Wang, Q. Dou. The construction of critical thinking ability model. Abroad and employment, 2014(20): 147-148.

[6] H. Chen, Z.Y. Cheng. Research on students thinking ability cultivation in college English reading teaching. Chinese Journal, 2014(11): 64-65, 95.

[7] F. Tian. Research on dynamic group cooperative learning in English teaching. Overseas English, 2012,14:27-28,31.

[8] C.L. Li. The role of the college students' thinking ability cultivation in English speaking teaching. Journal of Huaihai Institute of Techology, 2013(23): 61-63.

[9] G.W. Bao. The research on critical thinking skills training in higher vocational business English majors. Qiqihar Teachers College, 2013(6): 107-108.

[10] H.Y. Gu, H.Y. Zhang, W. Huang. Teaching skills and thinking ability. Journal of Huaibei Normal University, 2013(5):194-196.

[11] N. Miao, J.H. Ma. The research on the linguistics course reform based on the theoretical model of speculative ability. Teaching research, 2013(6): 78-80.

[12] W.X. Li. The abstract thinking ability of cultivation English major students in writing. Journal of Qinghai National University, 2014(6): 121-124.

[13] L. Zhao. The thinking ability of English class teaching and cultivation students. Journal of Wuhan Polytechnic, 2015(4): 65-67. 